\title{
MANAJEMEN LINEN PADA RUMAH SAKIT SITI KHODIJAH SIDOARJO TAHUN 2016
}

\author{
Nurfarida Safitri, A. T. Diana Nerawati, Demes Nurmayanti
}

\begin{abstract}
Linen is a material or a device made of fabric or woven. Linen from the hospital is not used directly in a treatment, yet the effect can be seen when its management is not good. Linen from the hospital will lead to disease transmission through crossinfection with linen as the medium of transmission of the disease. The purpose of this study was to determine the management of linen in laundry unit at Siti Khodijah Hospital, Sidoarjo.

This is a descriptive research describing the management of linen which includes the handling of linens, tools and materials, linen laundry, clean linen quality and the behavior of linen management officer in laundry unit of Siti Khodijah Hospital, Sidoarjo.

The results showed that the stage of collecting, transporting, sorting and washing did not meet the standard by 60\%, 70\%, 58\% and 70\% respectively. While drying and ironing, storage, distribution and laundry met the standard with the percentage of $80 \%, 75 \%, 80 \%$ and $75 \%$ respectively. The quality of clean linen from bacteriological aspect was qualified yet physically ineligible. The behavior of linen management officer was in "good" category (66.7\%).

In conclusion, the management of linen in laundry unit of Siti Khodijah hospital did not meet the standard (70\%). As an improvement, the hospital should have linen management training for officers, provide job descriptions or written and clear work division in unit laundry, pay more attention to the compliance of the officers in the use of personal protective equipment and compliance with Standard Operating Procedure (SOP) of hand washing. Officers should conduct physical checks on and maintain the cleanliness of the clean linen in the distribution process.
\end{abstract}

Keywords: Assessment, Linen management, Clean linen quality

\section{PENDAHULUAN}

Rumah sakit sarana pelayanan kesehatan, tempat berkumpulnya orang sakit maupun orang sehat, tempat penularan penyakit serta memungkinkan terjadinya pencemaran lingkungan dan gangguan kesehatan. (Kepmenkes RI No. 1204 Tahun 2004). Infeksi nosokomial yang memungkinkan dapat terjadi pada pasien saat dirumah sakit. Rumah sakit bertujuan memberi pelayanan kesehatan, yang meliputi pelayanan medis, penunjang medis dan penunjang non medis. Pelayanan medis tidak dapat berhasil, jika tidak didukung pelayanan penunjang medis dan pelayanan penunjang non medis. Unit laundry merupakan salah satu unit pelayanan penunjang non medis yang memberikan pelayanan linen terutama kepada pasien rawat inap. Rumah sakit harus bertanggung jawab dan perlu melakukan tindakan yang benar dalam hal pengelolaan linen pada unit laundry.

Meskipun linen tidak digunakan secara langsung dalam proses pengobatan namun pengaruhnya bila penanganan linen tidak dikelola dengan baik, mengakibatkan terjadinya penularan penyakit melalui infeksi silang.Hasil penelitian Tripradanti (2015) menyebutkan bahwa kurangnya sarana dan prasarana penunjuang pengelolaan linen di unit laundry dapat mempengaruhi efisiensi kerja dan pelayanan di unit tersebut.

Berdasarkan penelitian yang dilakukan oleh Eliya Ratnasari (2014) mengenai pengelolaan linen pada Instalasi Central Sterilisasi Supply
Departement (CSSD) dan Laundry di Rumah Sakit dr. M. Soewandhi Surabaya Tahun 2014 bahwa hasil pemeriksaan kualitas linen bersih didapatkan angka kuman spesies Bacillus tertinggi pada handuk pasien sebesar $2,71 \times 10^{2} /$ inchi $^{2}$ dan terendah pada handuk operasi sebesar $1,14 \times 10^{2} /$ inchi $^{2}$. Meskipun hasil tidak melebihi standart angka kuman, hal ini mengindikasikan bahwa adanya potensi bahaya biologi pada unit laundry. Sehingga pemakaian Alat Pelindung Diri (APD) sangat diperlukan karena petugas pengelola linen menerima ancaman potensial yang berupa bahaya biologi dari lingkungan kerja.

Rumah Sakit Siti Khodijah Sidoarjo merupakan rumah sakit umum kelas B di Sidoarjo dengan jumlah tempat tidur yang disediakan sebanyak 187 tempat tidur (bed) dan pemanfaatan tempat tidur (Bed Occupancy Rate) sebesar 51,5\%. Setiap harinya menerima linen kotor dari kegiatan pelayanan rumah sakit sebanyak $\pm 169 \mathrm{~kg}$ yang harus ditangani.

Kejadian infeksi nosokomial pada semester pertama (bulan Januari-Juni 2016) yang tercatat di Rumah Sakit Siti Khodijah adalah seperti berikut: Kejadian ILO 1\%; Kejadian ISK-CAUTI 12,5\%0; Kejadian VAP $0 \%$; dan rata- rata Kejadian Plebitis $23 \%$ per bangsal perawatan. Berdasarkan survei pendahuluan yang dilakukan pada pengelolaan linen, pewadahan/ pengantongan linen kotor antara linen infeksius dan non infeksius belum terlaksana dengan baik, dan beberapa petugas tidak memakai 
Alat Pelindung Diri (APD) dengan baik, benar dan lengkap pada tiap tahap pengelolaan linen. Oleh karena itu diperlukan pengelolaan linen yang baik

sebagai upaya pencegahan penyakit infeksi nosokomial. Penelitian ini bertujuan untuk mengetahui pengelolaan linen pada unit laundry di Rumah Sakit Siti Khodijah Sidoarjo.

\section{METODE PENELITIAN}

Penelitian ini adalah deskriptif, yaitu
menggambarkan pengelolaan meliputi identifikasi alat dan bahan, penanganan, tempat pencucian, kualitas linen bersih serta petugas pengelola linen di rumah sakit. Obyek atau sasaran adalah pengelolaan linen di Rumah Sakit Siti Khodijah Sidoarjo, yang meliputi pengumpulan, pengangkutan, pemilahan, pencucian, pengeringan dan penyetrikaan, penyimpanan, pendistribusian, alat dan bahan yang digunakan, tempat pengelolaan linen, kualitas linen bersih, baik secara fisik maupun bakteriologi serta perilaku petugas pengelola linen.

Teknik pengumpulan data dilakukan dengan cara observasi, wawancara, pengukuran dan pemeriksaan. Data yang terkumpul, selanjutnya diolah dan dianalisis secara deskriptif.

HASIL DAN PEMBAHASAN

\section{Identifikasi Alat dan Bahan Pengelolaan Linen}

Ketersediaan alat dan bahan pada unit laundry termasuk dalam kategori baik, karena hampir semua alat dan bahan terpenuhi. Namun, beberapa alat dan bahan tidak tersedia yaitu kantong plastik linen kotor, meja/ ruangan penerimaan, plastik pembungkus linen bersih, emulsifier dan starch/ kanji. Hanya terdapat 1 troli linen bersih yang tertutup, sedangkan jumlah linen bersih yang harus didistribusikan melebihi dari kapasitas troli tersebut. Hal yang menjadi potensi kontaminasi ulang yaitu ketika linen bersih didistribusikan dengan troli terbuka. Sehingga perlu ditingkatkan kebersihan linen pada proses distribusi khususnya distribusi dengan troli terbuka.

Tabel 1

Rekapitulasi Pengelolaan Linen Rumah Sakit Siti Khodijah Sidoarjo Tahun 2016

\begin{tabular}{|c|c|c|c|c|c|c|}
\hline \multirow{2}{*}{ No. } & \multirow{2}{*}{ Variabel } & \multirow{2}{*}{ Bobot } & \multicolumn{2}{|c|}{ Skor } & \multirow{2}{*}{ Persentase } & \multirow{2}{*}{ Kategori } \\
\hline & & & Maks & Observasi & & \\
\hline 1. & Pengumpulan & 2 & 200 & 120 & $60 \%$ & TMS \\
\hline 2. & Pengangkutan & 2 & 200 & 140 & $70 \%$ & TMS \\
\hline 3. & Pemilahan & 4 & 400 & 232 & $58 \%$ & TMS \\
\hline 4. & Pencucian & 7 & 700 & 490 & $70 \%$ & TMS \\
\hline 5. & $\begin{array}{l}\text { Pengeringan dan } \\
\text { Penyetrikaan }\end{array}$ & 2 & 200 & 160 & $80 \%$ & MS \\
\hline 6. & Penyimpanan & 3 & 300 & 225 & $75 \%$ & MS \\
\hline 7. & Pendistribusian & 2 & 200 & 160 & $80 \%$ & MS \\
\hline 8. & Tempat pencucian linen & 3 & 300 & 225 & $75 \%$ & MS \\
\hline & Total & 25 & 2500 & 1752 & $70 \%$ & TMS \\
\hline
\end{tabular}

Tahap Pengumpulan

Penilaian tahap pengumpulan linen kotor termasuk tidak memenuhi syarat (58\%). beberapa kriteria yang belum terpenuhi yaitu cara pengumpulan yang sering dicampur antara linen kotor infeksius dan non infeksius, tidak dilakukan perhitungan dan pencatatan linen kotor di bangsal perawatan, dan petugas pengumpul (petugas ruangan) tidak memakai alat pelindung diri dengan lengkap. Sebenarnya troli sudah dibedakan, hanya saja jika kapasitas kantong hitam tidak mencukupi untuk linen non infeksius petugas memasukkan ke dalam kantong kuning sehingga linen infeksius dan non infeksius tercampur. beberapa perawat yang melakukan verbeden (penggantian linen) langsung memasukkan linen kotor ke dalam troli tanpa membedakan antara linen infeksius dan non infeksius, serta tidak dihitung dan dicatat. Saat mengumpulkan linen kotor, petugas ruangan tidak menggunakan alat pelindung diri berupa masker.
Pemilahan antara linen kotor infeksius dan infeksius memiliki potensi bahaya besar terhadap petugas dan lingkungan, menyebabkan penyebaran mikroorganisme hidup seperti bakteri, virus, ricketsia, parasit dan jamur. Petugas menerima risiko bahaya saat kontak dengan linen kotor dan menghirup udara yang tercemar kuman patogen. Kegiatan pemilahan mulai dari sumber diatas berkaitan dengan penelitian yang dilakukan Sri Lestari (2010) yang menyatakan praktek perawat dalam pengelolaan linen dipengaruhi oleh ketersediaan fasilitas. Bagaimana seseorang akan berperilaku baik dalam pengelolaan linen apabila tidak ada fasilitas yang mendukung praktek tersebut.

Tahap Pengangkutan

Berdasarkan hasil penilaian, tahap pengangkutan linen kotor tidak memenuhi syarat dengan nilai prosentase $70 \%$. Pengangkutan dilakukan oleh petugas ruangan dengan menggunakan troli linen 
yang terbuat dari bahan tahan karat dan mudah dicuci serta dilengkapi dengan tutup. Troli dibedakan dari segi desain dan warna dengan troli linen bersih yang digunakan saat distribusi. Akan tetapi setalah pengangkutan linen kotor, troli tidak segera dicuci meskipun bahan troli termasuk mudah dicuci, karena troli akan dicuci jika sangat kotor. Penelitian bakteriologis pada instalasi pencucian menunjukkan bahwa jumlah total bakteri meningkat 50 kali selama periode waktu sebelum cucian diproses. (Depkes RI, 2004). Troli linen kotor tersebut sering ditemukan beberapa sampah seperti botol air mineral, kapas dan masker karena pasien atau pengunjung menganggap troli sebagai tempat sampah. Troli linen kotor segara dicuci, agar tidak ada penambahan kotoran pada linen kotor. Petugas pengangkut sudah memakai alat pelindung diri seperti sarung tangan dan sepatu kerja, tetapi tidak memakai masker dikarenakan troli linen kotor tertutp dengan rapat sehingga potensi bahaya terhadap petugas dapat berkurang.

\section{Tahap Pemilahan}

Memudahkan proses pencucian maka salah satu cara yang harus dilakukan adalah pemilahan linen kotor terlebih dahulu. Tahap pemilahan linen kotor termasuk dalam kategori tidak memenuhi syarat (58\%). Pemilahan dilakukan berdasarkan linen infeksius dan non infeksius, dilanjutkan pemilahan linen non infeksius berdasarkan jenisnya saja tidak dipilah lagi berdasarkan kotorannya, dikarenakan sebagian besar petugas pengelola linen tidak mengetahui cara pemilahan tersebut. Petugas pengelola linen di laundry harus melakukan pemilahan pada seluruh linen yang diterima. Menurut Depkes RI (2004) pemilahan linen infeksius sangat tidak dianjurkan, pemisahan wadah atau kantong ketika pengumpulan merupakan upaya untuk menghindari pemilahan. Pemilahan linen infeksius akan mengkontaminasi pekerja sehingga menimbulkan penyakit dan menjadi sumber kontaminasi linen bersih.

Petugas laundry pada saat pemilahan tidak memakai alat pelindung diri seperti masker dan sepatu. Pemakaian masker bertujuan untuk mencegah membran mukosa petugas kontak dengan darah dan cairan tubuh pasien yang terdapat di linen kotor, mengurangi bau linen kotor, mengurangi risiko terhirupnya virus yang ada pada linen kotor serta menghindari debu yang terhirup oleh petugas. (Hakim, 2015).

Tahap Pencucian

Tahap pencucian linen kotor tidak memenuhi syarat (70\%). Pencucian linen hanya berdasarkan jenisnya tidak berdasarkan kekotorannya, kemudian petugas (bagian mesin) sering kali kontak dengan linen bersih yaitu setelah memasukkan linen kotor ke dalam mesin cuci, kemudian petugas memasukkan linen bersih ke dalam mesin pengering dengan memakai sarung tangan yang sama, tanpa melepas sarung tangan kemudian langsung memasukkan linen bersih ke dalam mesin pengering tanpa mencuci tangan terlebih dahulu. Petugas pencucian juga tidak memakai alat pelindung diri seperti masker, apalagi saat melakukan pembersihan linen kotor dari tinja, urin, darah dan muntahan. Sehingga pada kegiatan pembersihan ini akan memicu terjadinya infeksi atau timbulnya penyakit karena kontak dengan linen kotor yang mungkin terdapat mikroorganisme hidup dan udara yang tercemar kuman patogen terhirup oleh petugas pengelola linen.

Tahap Pengeringan dan Penyetrikaan

Pada tahap ini unit laundry Rumah Sakit Siti Khodijah Sidoarjo telah memenuhi syarat (80\%) dan telah dilakukan dengan baik. Linen setelah proses cuci dan peras langsung dilakukan pengeringan menggunakan mesin pengering dengan suhu $70^{\circ} \mathrm{C}$ dan dibantu sinar matahari. Linen bersih yang sudah kering tidak diperkenankan kontak dengan linen kotor, setelah linen keluar dari mesin pengering segera dilakukan penyetrikaan, dan dibedakan berdasarkan jenisnya. Diharapkan dengan pengeringan dan penyetrikaan linen pada suhu yang telah sesuai tersebut dapat mematikan mikroorganisme yang masih menempel pada linen sehingga akan memberikan kualitas linen yang aman secara bakterologis. Suhu pada pengeringan dan penyetrikaan harus dipertahankan, karena jika linen masih lembab akan memicu tumbuhnya bakteri atau kuman pada linen. Adapun hal yang belum terpenuhi yaitu petugas yang menangani linen bersih tidak mencuci tangan terlebih dahulu sebelum memegang linen bersih, Penelitian Tripradanti (2015) menyatakan bahwa mencuci tangan merupakan hal yang penting untuk dilakukan oleh petugas pengelola linen, karena tangan yang kotor akan mengancam kesehatan petugas dan dapat memindahkan bakteri atau virus patogen dari tubuh ke linen bersih.

\section{Tahap Penyimpanan}

Tahap penyimpanan linen bersih memenuhi syarat (75\%). Hampir semua kriteria yang dinilai terpenuhi yaitu telah terdapat lemari penyimpanan dalam keadaan baik (dapat ditutup dengan rapat), bersih bebas debu dan binatang. Cara penyimpanan linen dipisahkan berdasarkan jenisnya, hal ini akan memudahkan petugas ruangan dan perawat dalam pengambilan linen. Tahap penyimpanan linen bersih sudah baik dan perlu dipertahankan untuk meningkatkan pelayanan linen rumah sakit. Tetapi saat penyimpanan, linen tidak dibungkus dengan plastik transparan. Pembungkusan linen bersih tidak hanya dengan plastik transparan, bisa juga dengan linen atau linen lain yang bersih. Jika penyimpanan memang tidak dilakukan dengan pembungkusan terlebih dahulu, sebaiknya menjaga kondisi lemari penyimpanan agar selalu bersih, bebas debu dan bebas serangga.

Tahap Pendistribusian

Membagikan linen bersih ke unit yang membutuhkan dan pencatatan linen yang keluar dengan sistem FIFO (First In First Out) agar tidak ada linen yang mengendap terlalu lama di ruang penyimpanan merupakan tahap akhir dari 
penanganan linen di rumah sakit. Tahap pendistribusian linen bersih telah memenuhi syarat (80\%). Pencatatan sebelum linen didistribusikan telah dilakukan dengan baik, kereta dorong atau troli telah dibedakan antara linen linen bersih dan linen kotor, pendistribusian disesuaikan menurut ruangan, penyerahan linen bersih kepada petugas ruangan sesuai dengan kartu tanda terima. Tetapi penyimpanan pada unit laundry maupun di bangsal perawatan Rumah Sakit Siti Khodijah Sidoarjo tidak menerapkan sistem FIFO (First In First Out), karena pelayanan linen unit laundry belum tersentral, sehingga penyimpanan di ruang laundry bersifat sementara. Penyimpanan di bangsal perawatan belum menerapkan sistem FIFO karena ketersediaan linen kurang. Hal ini memungkinkan pemakaian satu linen secara berulang-ulang, sehingga akan mempengaruhi mutu linen. Kasus kehilangan linen dan linen tertukar juga sering terjadi, karena penyerahan linen bersih memang telah sesuai dengan kartu tanda terima tetapi tidak ada serah terima secara langsung antara petugas distribusi dan petugas ruangan sehingga tidak dilakukan pengecekan linen yang diterima di bangsal perawatan.

Tempat Pencucian Linen

Kualitas Linen Bersih Secara Fisik dan Bakteriologi

Hasil Observasi Kualitas Linen Bersih Secara Fisik di Rumah Sakit Siti Khodijah Sidoarjo Tahun 2016

\begin{tabular}{|c|c|c|c|c|}
\hline \multirow[t]{2}{*}{$\begin{array}{c}\text { Syarat } \\
\text { Pemenuhan }\end{array}$} & $\begin{array}{c}\text { Hasil } \\
\text { Observasi } 1\end{array}$ & $\begin{array}{c}\text { Hasil } \\
\text { Observasi } 2\end{array}$ & \multirow{2}{*}{$\begin{array}{l}\text { Hasil } \\
\text { Observasi } 3 \\
\text { Ya Tidak } \\
\end{array}$} & \multirow[t]{2}{*}{ Skor } \\
\hline & Ya Tidak & Ya Tidak & & \\
\hline Linen bersih harum & $\mathrm{V}$ & $\mathrm{V}$ & $\mathrm{V}$ & 3 \\
\hline Tidak terdapat noda & $\mathrm{V}$ & $\mathrm{V}$ & $\mathrm{V}$ & 3 \\
\hline Tidak Kusam dan pudar & $\mathrm{V}$ & $\mathrm{V}$ & $\mathrm{V}$ & 1 \\
\hline Terlipat dengan rapi & V & V & V & 1 \\
\hline Tidak Kusut & V & $\mathrm{V}$ & V & 1 \\
\hline
\end{tabular}

Hasil observasi menujukkan bahwa kualitas fisik linen bersih tidak memenuhi syarat menurut Pedoman Manjemen Linen di Rumah Sakit, Depkes RI (2004) yaitu masih terdapat linen bersih yang kusam dan pudar. Lipatan pada beberapa linen

Tabel 3

Hasil Pemeriksaan Mikrobiologi Usap Linen Bersih

\begin{tabular}{lll}
\hline No. & \multicolumn{1}{c}{ Sampel } & Hasil (Spora Baciilus) \\
\hline 1. & Perlak & Negatif \\
\hline 2. & Sprei & Negatif \\
\hline 3. & Selimut Lurik & Negatif \\
\hline 4. & Sarung Bantal & Negatif \\
\hline 5. & Popok Bayi & Negatif \\
\hline 6. & Gedong Bayi & Negatif \\
\hline 7. & Stiklaken & Negatif \\
\hline
\end{tabular}

Tempat pencucian linen (laundry) telah memenuhi syarat (75\%). Lokasi unit laundry termasuk dijangkau oleh unit yang membutuhkan, lantai tempat pencucian terbuat dari konstruksi yang kuat, rata, tidak licin dengan kemiringan $2-3 \%$, dan pencahayaan $>200$ lux ditempat pencucian. Ruangan pada unit laundry termasuk sudah baik yaitu tersedia ruang pemisah antara barang kotor namun tata letak sedikit kurang tepat seperti area linen kotor yang digunakan untuk pemilahan linen kotor menjadi satu tempat dengan mesin cuci linen infeksius sehingga linen setelah proses cuci dan peras sangat mungkin terkontaminasi dari linen kotor yang dipilah. Pada unit laundry ini tidak terdapat sarana pengering untuk alat-alat seperti timba, bak dan sikat cuci sehabis proses cuci, alatalat tersebut setelah digunakan tetap diletakkan di tempat pencucian tetapi sudah dalam keadaan bersih, meskipun begitu didalam timba biasanya masih terdapat air sehingga akan menyebabkan timba cepat berlumut.

Ditinjau dari seluruh tahapan penanganan linen serta tempatnya, pengelolaan linen di Rumah Sakit Siti Khodijah Sidoarjo memperoleh skor 1752 dengan persentase sebesar $70 \%$.

bersih sedikit tidak rapi dan masih kusut. Hal ini terjadi karena tidak dilakukan pengecekan secara fisik pada linen bersih saat penyetrikaan dan kepuasan pasien dalam pelayanan pelipatan. 
Mutu linen bersih secara fisik sangat berkaitan dengan Mutu linen secara bakteriologis akan menjamin pasien aman terhadap rantai penularan penyakit terutama infeksi nosocomial. Sampel linen menujukkan bahwa secara bakteriologi linen bersih, telah memenuhi syarat berdasarkan Kepmenkes No. 1204 tahun 2004, yang menyebutkan standar kuman linen bersih setelah keluar dari proses tidak mengandung $6 \mathrm{x}$ $10^{3}$ spora spesies Bacillus/inchi ${ }^{2}$

\section{Perilaku Petugas Pengelola Linen}

Tabel 4

Penilaian Perilaku Petugas Pengelola Linen di Rumah Sakit Siti Khodijah Sidoarjo 2016

\begin{tabular}{cccccc}
\hline \multirow{2}{*}{ No. } & Aspek & \multicolumn{4}{c}{ Jumlah Petugas } \\
\cline { 3 - 6 } & \multirow{n}{*\wedge\text{Kriteria}}{} & $\begin{array}{c}\text { Tingkat } \\
\text { Pengetahuan }\end{array}$ & Sikap & Tindakan & Perilaku \\
\hline 1. & Baik & $2(33,3 \%)$ & $6(100 \%)$ & $0(0 \%)$ & $4(66,7 \%)$ \\
\hline 2. & Cukup & $4(66,7 \%)$ & $0(0 \%)$ & $6(100 \%)$ & $2(33,3 \%)$ \\
\hline 3. & Kurang & $0(0 \%)$ & $0(0 \%)$ & $0(0 \%)$ & $0(0 \%)$ \\
\hline \multicolumn{7}{c}{ Total } \\
\hline
\end{tabular}

Petugas pengelola linen sebanyak 4 orang memiliki perilaku yang baik berdasarkan dari penilaian tingkat pengetahuan, sikap dan tindakan. Pendidikan seseorang akan mempengaruhi pengetahuannya, kemampuan menerima dan memahami informasi yang diberikan. Tingkat pengetahuan mempengaruhi perilaku setiap individu. Penilaian pengetahuan dalam penelitian ini terdiri dari pengetahuan petugas tentang cara pengelolaan linen, alat, bahan dan alat pelindung diri yang diperlukan dalam pengelolaan linen. Pengetahuan petugas termasuk dalam kategori cukup baik $(66,7 \%)$, karena rata-rata tingkat pendidikan petugas adalah SD dan SMP. Sebagian besar petugas belum mengetahui cara pengelolaan linen yang benar seperti pemilahan, pencucian, dan penyimpanan linen yang benar. Penilaian sikap yaitu tanggapan petugas mengenai tata laksana pengelolaan linen. Sedangkan tindakan dinilai berdasarkan aktivitas petugas dalam melaksanakan pengelolaan linen termasuk pemakaian alat pelindung diri dan mencuci tangan sebelum menangani linen bersih. Petugas memiliki sikap yang baik dan seluruh (100\%), cukup baik untuk tindakan petugas. Hal ini disebabkan bahwa sikap yang sudah baik tidak secara otomatis akan mengambarkan tindakan yang baik pula. Menurut Notoatmodjo (2011) dalam teori perilaku dijelaskan bahwa suatu sikap belum otomatis terwujud dalam suatu tindakan (overt behavior). Mewujudkan sikap menjadi suatu perbedaan nyata diperlukan faktor pendukung seperti fasilitas dan dukungan (support) rekan kerja serta atasan.

\section{DAFTAR PUSTAKA}

Depkes RI, 1995. Pedoman Sanitasi Rumah SakitDiIndonesia. Jakarta: Dirjen PPM \& PLP Departemen Kesehatan RI: 94-98

Depkes RI, 2004. Pedoman Manajemen Linen di Rumah Sakit. Jakarta. Dirjen Pelayanan Medik, Departemen Kesehatan RI: 7-21.

Eliya Ratnasari, E, 2014. Pengelolaan Linen Pada Instalasi Central Steri/isasi Supply

\section{KESIMPULAN}

Pengelolaan linen pada unit laundry di Rumah Sakit Siti Khodijah Sidoarjo termasuk tidak memenuhi syarat, dilihat dari alat dan bahan dalam pengelolaan linen pada unit laundry yang telah tersedia, dalam kategori baik dari segi kuantitas dan kualitas. Tahap pengumpulan, pengangkutan, pemilahan, dan pencucian linen kotor tidak memenuhi syarat. Tahap pengeringan dan penyetrikaan, penyimpanan, pendistribusian linen bersih serta tempat pencucian linen (laundry) telah memenuhi syarat. Kualitas linen bersih secara bakteriologis sudah memenuhi syarat, sedangkan secara fisik belum memenuhi syarat. Perilaku petugas pengelola linen pada unit laundry termasuk dalam kategori baik.

\section{SARAN}

1. Bagi pihak rumah sakit sebaiknya mengadakan pelatihan pengelolaan linen bagi petugas, dibuat uraian tugas atau pembagian kerja secara tertulis dan jelas pada unit laundry, lebih memperhatikan kepatuhan petugas dalam pemakaian alat pelindung diri dan kepatuhan mencuci tangan sesuai dengan SOP (Standar Operasional Prosedur).

2. Bagi petugas sebaiknya melakukan pengecekan fisik linen bersih dan menjaga kebersihan linen bersih pada proses pendistribusian dengan memberikan penutup berupa kain atau plastik diatas linen bersih yang didistribusikan menggunkan troli terbuka.

Departement (CSSD) dan Laundry di Rumah Sakit dr. M. Soewandhi Surabaya Tahun 2014. Surabaya: Jurusan Kesehatan Lingkungan, Poltekkes Surabaya.

Hakim, Nurul Radhiyah, 2015. Pemakaian Alat Pelindung Diri Dalam Memberikan Perlindungan Bagi Tenaga Kerja di Instalasi Linen-Laundry Rumah Sakit PKU 
Muhammadiyah Surakarta.

Laporan Tugas Akhir. Surakarta. Prodi D3 Hiperkes dan Keselamatan Kerja, Fakultas Kedokteran Universitas Sebelas Maret.

Keputusan Menteri Kesehatan RI No. 1204/MENKES/SK/X/2004. Tentang Persyaratan Kesehatan Lingkungan Rumah Sakit.

Lestari, F.S., dan Mahawati, E., 2010. Faktor-faktor Yang Berhubungan dengan Praktek Pengelolaan Linen oleh Perawat di Ruang Rawat Inap RSUD Kota Semarang 2010, Jurnal Visikes, (Vol.9 No.1).

Notoatmodjo, Soekidjo. 2011. Kesehatan Masyarakat iimu dan Seni. Jakarta: Rineka
Cipta.

Sanropie, Djasio dkk, 1989. Komponen Sanitasi Rumah Sakit Untuk Institusi Pendidikan Tenaga Sanitasi. Jakarta. Departemen Kesehatan RI: 38-42.

Tarupolo, Bambang, dkk. 2001. Pedoman Teknis Upaya Kesehatan Kerja Di Rumah Sakit. Jakarta. Departemen Kesehatan RI: 29-31

Tripradanti, Oksi, 2015. Kajian Pengelolaan Linen di Instalasi Central Sterile Supply Departement (CSSD) dan Laundry RSUD Dr. Iskak Tulungagung. Skripsi. Jember: Fakultas Kesehatan Masyarakat, Universitas Jember. http://repositorv.unei.ac.id Diakses pada tanggal 03 Februari 2016. 